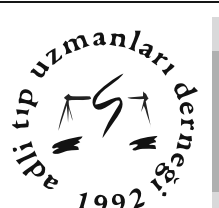

1992

\title{
Considerations on Liver Injuries Caused by CPR: Case Presentation
}

\author{
Kardiyopulmoner Resüstasyonun Neden Olduğu Karaciğer Yaralanmalarının \\ Değerlendirilmesi: Olgu Sunumu
}

Beatrice Ioan, Bianca Hanganu, Marius Neagu

Grigore T. Popa University of Medicine and Pharmacy, Institute of Legal Medicine, Iasi, Romania

\begin{abstract}
Cardiac arrest is a life-threatening condition which requires fast maneuvers for saving the victim's life. Cardio-pulmonary resuscitation (CPR) is one of the easiest and handiest maneuver which proved many times to be savior even though sometimes it could worsen the victim's prognosis. In this paper the authors present the case of a 75-year old male, with a significant medical history and long term thrombolytic treatment who suffered a witnessed cardiac arrest. The emergency team who arrived at the victim's home initiated the CPR and transported him to the hospital. The electrocardiogram showed inferior-lateral acute myocardial infarction and the cardiologist in the emergency room decided to transfer him to another hospital for specialized treatment. Despite the fact that the CPR was continued in the ambulance in order to maintain the cardiac activity, the blood pressure decreased gradually and he died couple of hours later. Internal examination at the autospy revealed multiple injuries caused by the cardiac massage: rib and sternum fractures, massive intraperitoneal bleeding, liver laceration and contusion. This paper brings to the attention of the physicians the issue of the iatrogenic injuries following the CPR and the possibility for these injuries to contribute to thanatogenesis. The authors also analyze the factors influencing the quality of the life-saving procedures and the role of the pathologist in establishing the correct cause of death taking into the gravity of the CPR related injuries.
\end{abstract}

Keywords: CPR, Liver injury, Death.

\section{Introduction}

Cardiac arrest is a life-threatening condition which requires fast cardio-pulmonary resuscitation (CPR), this being the easiest and the handiest life- saving procedure. The success of the cardio-pulmonary resuscitation is strictly related to the quality of the delivered chest compression (1), the European Resuscitation Council (2010) Guidelines for CPR recommending that sternum compression depth should be 5-6 $\mathrm{cm}$, and the rate compression at least $100 / \mathrm{min}$ (2). However, these maneuvers may induce severe injuries of the thoracic wall and of the internal organs $(2,3)$, the iatrogenic injuries

Corresponding Author: Beatrice Ioan

M.D., Ph.D., Associate Professor, senior Forensic Pathologist,

Grigore T. Popa University of Medicine and Pharmacy,

Institute of Legal Medicine, Iasi, Romania

E-mail: ioanbml@yahoo.com

Geliş: 06.04.2015

Düzeltme: 07.04.2015

\section{Özet}

Kardiyak arrest kurbanın hayatını kurtarmak için hızlı manevralar gerektiren yaşamı tehdit eden bir durumdur. Kardiyopulmoner resüstasyon (KPR) bazen kurbanın porgnozunu kötüleştirebilse bile, çoğu kez hayat kurtarıcı olduğu kanıtlanmış olan kolay ve elverişli bir manevradır. Bu yazıda ciddi bir tıbbi hikayesi ve uzun dönem trombolitik tedavi alan ve kardiyak arrest olan 75 yaşındaki erkek olgu sunılmuştur. Acil ekibi tarafından kurbanın evine ulaşıldı, KPR'e başlandı ve kurban hastaneye nakledildi. Elektrokardiyogramında inferior-lateral akut myocardial enfarktüs tespit edildi ve acil servisteki kardiyolog tarafından daha ileri tedavi için başka hastaneye transfer edilmesine karar verdi. Kardiyak aktiviteyi korumak için ambulansta KPR sürekli yapılmasına yavaş yavaş kan basıncı düştü ve birkaç saat sonra öldü. Otopside iç muayenede, kalp masajından kaynaklı kaburga ve sternum kırıkları, masif intraperitoneal kanama, karaciğer laserasyonu ve kontüzyonu gibi multipl yaralanmalar saptandı. Bu makale, KPR sonrası iyatrojenik yaralanmalar konusunda doktorların dikkatini çekmek ve bu yaralanmaların tanatogenesis üzerindeki etkilerin anlaşılmasında katkıda bulunmayı amaçlamaktadır. Yazarlar ayrıca KPR ilişkli yaralanmaların ağırlık derecelerini dikkate alarak ölüm nedenini doğru tespit edilmesinde patologların rolü ve hayat kurtaran prosedürlerin kalitesini etkileyen faktörlerin etkisini de analiz etmektedir.

Anahtar kelimeler: Kardiyopulmoner resüstasyon, Karaciğer yaralanması, Ölüm.

related to the CPR first being described by Baringer et al. in $1961(2,4)$.

The injuries during CPR may occur due to several factors such as: duration of resuscitation - the longer the duration of the CPR the more likely the occurrence of resuscitation injuries, although in some cases major injuries may occur from the very beginning $(5)$, patient's sex and age $(3,6)$, the female gender presenting a higher risk due to the connection with the osteoporosis and the different shapes of the chest, and older people having natural degenerative skeletal changes (5). Intensity of the resuscitation attempt (6), degree of qualification of the emergency personnel (3), depth and rate of compression-decompression maneuver $(2,7)$, and excessive pressure on the chest (8) have also been related to a higher risk of injuries. Some diseases like osteoporosis and hyperparathyroidism as well as alcohol consumption and 
smoking have their own influence in the occurrence of the injuries (2).

The gravity of the CPR related injuries is very variable. Studies show that the less frequent a CPR injury is the more life threatening it may be.

The most common CPR related injuries are located on the thorax and affect especially the skeleton: rib fractures, fractures of the sternum $(3,7)$ and flail chest $(7)$. Nevertheless, in children, whose thoracic cage is still quite elastic, bone injuries are rarely reported $-0-2 \%$ [9]. Lesions of the thoracic viscera, sometimes associated with hemo/pneumothorax [10], have also been described.

Usually, the abdominal viscera are less damaged than the thoracic viscera, the most frequent lesions being located in the organs from the top of the abdomen (liver, spleen, stomach, and pancreas) in children having an increased susceptibility for ruptures of the abdominal viscera during CPR (10). The liver is the most commonly injured during the CPR, the frequency of the lesions being differently reported by various studies $(4,6)$.

Injuries of the organs are mainly produced by penetration of the tips of the fractured ribs and sternum $(4,6)$, but also indirectly by the force of compression being transmitted to the internal organs due to the unstable chest caused by bone fractures $(6,7,11,12)$.

In this paper the authors present a case of CPR related liver laceration which raised questions about the possible contribution of this injury to the death of the patient and discuss it in the context of the literature data.

\section{Case Report}

A 75-year old, bedridden male, with a significant medical history (type II diabetes complicated with diabetic sensorimotor polyneuropathy, hypertension, stroke sequels, suppurated cellulitis), was found in his house by the ambulance at 07:30 a.m. in cardiac arrest. The emergency team started the CPR immediately and also administered two ampoules of adrenaline followed by resumption of cardiac activity with a cardiac rate of 48/minute and a blood pressure of 144/109 $\mathrm{mmHg}$. The electrocardiogram showed inferior-lateral and right ventricle acute myocardial infarction. The CPR continued in the ambulance while the patient was being transported at the hospital. Upon arrival at the hospital, at 08:30 am, the patient was intubated and mecanically ventilated, with a heart rate of $68 /$ minute and a blood pressure of $108 / 83 \mathrm{mmHg}$. While moving the patient from the stretcher to the bed the heart rhythm became idioventricular and the CPR was resumed in parallel with the administration of adrenaline, dopamine, dobutamine, and heparine. The heart rate at 9.40 am was $49 /$ minute, and decreased to $39 /$ minute at 9.58 am. A cardiac pacing was fitted, followed by an increase of the heart rate at $70 /$ minute. Laboratory analysis showed an increased level of the myocardial necrosis enzymes (CKMB- 13,2 ng/ml, MYO> 500 ng/ml, TNI- 7,45 ng/ml, BNP- 354 pg/ml, DDIM- 4980 $\mathrm{ng} / \mathrm{ml}$ ). Echocardiographic examination showed hypertrophy of the left ventricle, calcification of the atrio-ventricular valves, mitral and tricuspid failure, and akinesia of the inferior part of the left ventricle. Following the consultation by a cardiologist it was decided that the patient be transferred to the institute for cardio-vascular diseases in the same city, for the specialized treatment of the acute myocardial infarction. Despite the fact that the CPR was continued in the ambulance in order to maintain the cardiac activity, the blood pressure decreased gradually. Upon arrival at the institute for cardio-vascular diseases the blood pressure was zero and the EKG showed asystole. Death was declared at 10:17 am in the same day.

The autopsy was performed after 24 hours from death. External exam of the body showed pale cadaveric lividity spread over a small surface on the dorsal part of the trunk (Fig 1) and multiple needle punctures. The internal examination of the thoracic and abdominal cavities showed many injuries: extensive hemorrhagic infiltration of the thoracic muscles, multiple bilateral rib fractures (Fig 2, Fig 3) and two horizontal fractures of the sternum.

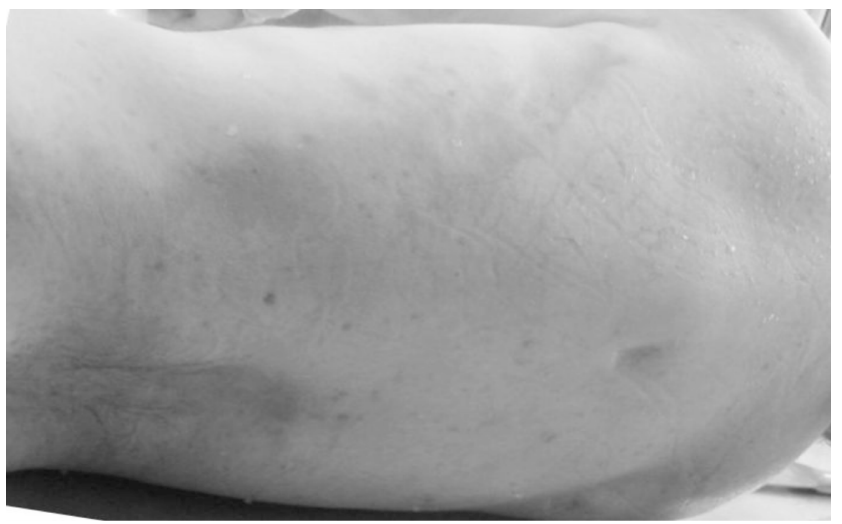

Fig 1. Pale cadaveric lividity

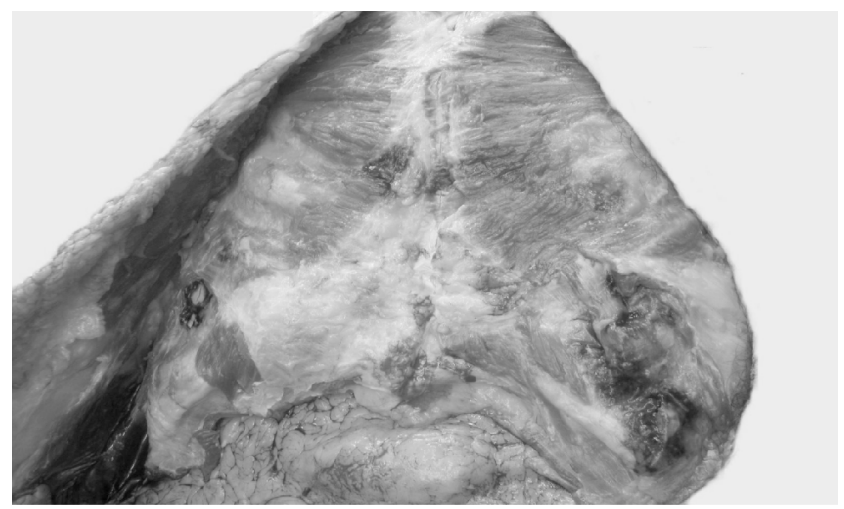

Fig 2. Hemorrhagic infiltration (thoracic muscles) 


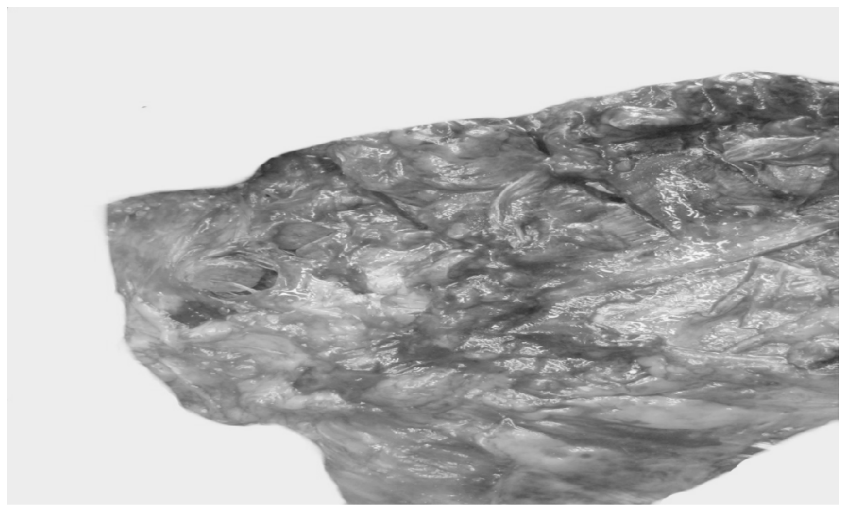

Fig 3. Multiple bilateral rib fractures

The pleural cavities contained a small amount of blood, measuring $50 \mathrm{ml}$ on the left side and $100 \mathrm{ml}$ on the right side. We also found an area of $5 / 10 \mathrm{~cm}$ of hemorrhagic infiltration of the pericardium, hemorrhagic infiltration of the ilium muscle and $3500 \mathrm{ml}$ of fluid blood mixed with clots in the peritoneal cavity. Examination of the liver showed hemorrhagic infiltration across the falciform ligament, laceration of the underneath parenchyma (Fig 4), area of laceration across the left half of the coronary ligament and an area of about $5 / 10 \mathrm{~cm}$ of laceration affecting the whole thickness of the left lobe (Fig 5). The hepatic injuries were an autopsy surprise as we found no information about liver injuries or clinical signs evocative for these in the patient's medical file.

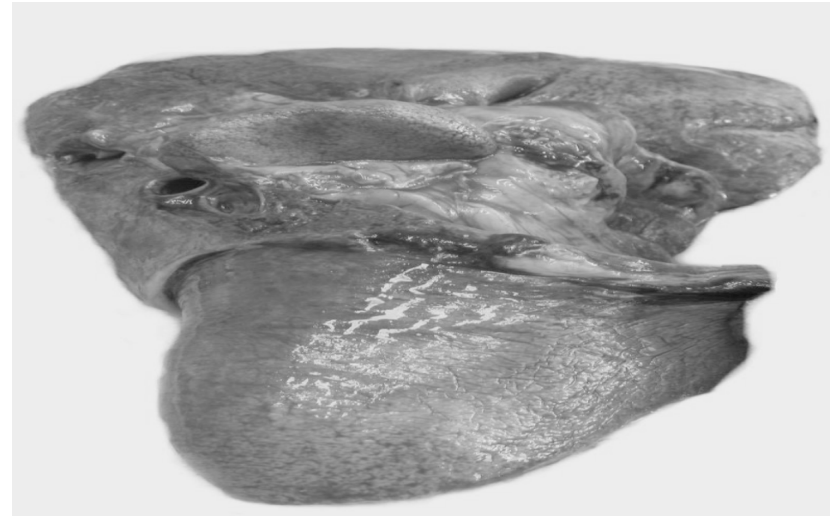

Fig 4. Falciform ligament - hemorrhagic infiltration

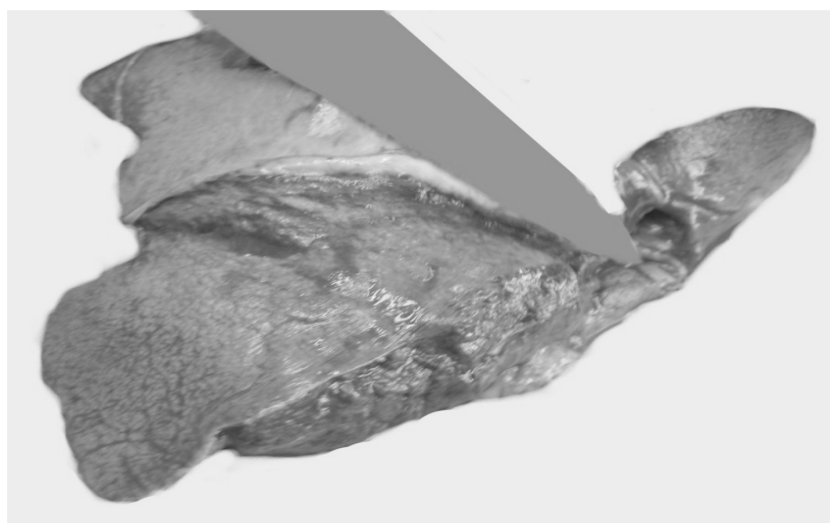

Fig 5. Liver laceration
The examination of the heart revealed important chronic pathological lesions: extensive coronary and aortic atherosclerosis, and extensive myocardial fibrosis. On the right ventricle wall and in the inferior part of the interventricular septum we noticed the area of acute myocardial infarction with a slightly pale aspect surrounded by bright red lines.

\section{Discussion}

Liver laceration is a rare complication of the CPR, its frequency being widely reported in different studies. For example, in a study on 2558 cases Meron et al. identified liver injuries in $0,6 \%$ of the cases (8). The frequency of hepatic injuries on 557 cases was $2,9 \%$ (13). Clark reports a frequency of $21 \%$ of liver injuries after manual CPR (14) and Krischer et al. noted ribs fractures associated with liver ruptures in $73 \%$ of cases (15).

Liver injuries are many times associated with technique deficiences $(8,11)$ such as caudal pressure on the sternum, especially if the liver is destended as in cardiac congestive failure $(16,17)$, or excessive pressure during thoracic compressions (18). Still, a perfect technique does not guarantee that the liver injury will not occur. When CPR is performed in difficult conditions, as in ambulance, it may also result in liver injuries $(5,11)$.

Thrombolytic treatment represents an important risk factor for spontaneous liver bleeding $(6,15,19,20)$, whose relevance increases in association with $\mathrm{CPR}$, which, in turn, is a risk factor for the liver laceration (8).

Most of the liver injuries involve the left lobe, due to its anatomical location, close to the medial line, but the right lobe may be injured, too $(8,19)$. Pollak et al, in a study on autopsy cases, showed that the most frequent CPR related liver lacerations appear on the medial line $(8,21)$.

According to the clinical aspects and the required treatment, the liver injuries produced during CPR may be classified as follows:

- Life-threatening injuries- those lesions which determine important blood loss (more than $800 \mathrm{ml}$ ), which interfere with the cardio-circulatory and/ or respiratory function, by depriving the tissues of blood and oxygen;

- Consequential injuries, which require treatment for solving the liver injuries, and determine prolonged hospitalization;

- Insignificant injuries, which do not need specific treatment, heal spontaneously or require limited treatment $(8,22)$.

The liver laceration is not always clinically obvious (8). Hypovolemia due to bleeding may be misplaced on account of 
reperfusion disorders and hemodynamic instability secondary to a reversible myocardial dysfunction. However, the suspicion of intraperitoneal bleeding due to abdominal viscera laceration must be raised in a patient who is treated with anticoagulant medication, who shows clinical signs of hypovolemic shock, persistent hemodynamic instability, low central venous pressure, enlargement of the abdominal diameter, and low or decreasing hematocrit following $\operatorname{CPR}(8,13,16,19)$.

Injuries of the internal organs following CPR may negatively influence the morbidity and mortality in patients receiving CPR. However, liver rupture alone can only slightly influence the overall prognosis of the patient, unless it is not correctly treated $(8,19)$. Therefore even if they will never be completely avoidable they need to be recognized in order for the appropriate medical treatment to be applied to the surviving patients $(3,7,8,12,16,19)$.

In our case, the liver injuries (extensive lacerations, hemorrhagic infiltrations) followed by massive intraperitoneal bleeding were produced in the context of several contributing factors relating to both the patient and the conditions of performing the CPR. The patient was an old person with osteoporosis, which favored the production of multiple rib and sternum fractures allowing the transmission of the pressure to the internal organs during the chest compression. The patient was also suffering from multiple comorbidities, and was on long term treatment with thrombolytic medication. Due to the complex chronic cardiac pathology (i.e. hypertension, myocardial fibrosis and atherosclerosis), the liver reacted by enlarging its dimensions, changing its structure and becoming easily friable. These changes increased the risk of injuries while the CPR maneuvers were being performed. The occurrence of the liver injuries was also favored by the CPR being performed for a long time, mostly in improper conditions, i.e. in the ambulance, while the patient was transported by the ambulance from his home to the hospital or between hospitals.

The liver injuries and the intraperitoneal bleeding were not diagnosed during the patient's life, the clinical signs determined by these injuries overlapping and being mistaken for the cardiac and circulatory instability determined by the acute myocardial infarction. Therefore no treatment to address these injuries was applied.

In our case the extensive area of acute myocardial infarction was the cause of cardiac arrest and the reason for which the CPR had to be continued for almost all the time since the patient was taken by the ambulance from his home till his death. Still, given the gravity of the liver laceration and the massive intraperitoneal bleeding, we cannot exclude the implication of the liver lesions in thanatogenesis by worsening the cardio-circulatory failure caused by the extensive acute myocardial infarction.

\section{Conclusion}

The risk of iatrogenic CPR-related trauma is even present with adequate CPR technique $(8,11)$, especially in the context of specific risk factors. However, the possibility of iatrogenic injuries should not question the employment of CPR as this may be the only life-saving procedure in many cases. AHA Guidelines itself states that “(...) concern for injuries that may complicate CPR should not impede prompt and energetic application of CPR. The only alternative to timely initiation of effective CPR for the victim of cardiac arrest is death" (10).

Liver is the abdominal organ most frequently damaged during CPR. The liver injuries may be of variable gravity and their influence on the vital prognosis depends on the type of injury and its timely treatment.

The forensic pathologist must be familiar with the injuries induced by CPR and able to distinguish them from trauma that occurred prior to the resuscitation procedure $(3,4,6,23,24)$. Moreover, severe post-resuscitation injuries bring to the attention of the forensic pathologist the issue of the careful evaluation of their involvement in the death mechanism (3).

\section{References}

1. Rajab TK, Pozner CN, Conrad C, Cohn LH, Schmitto JD. Technique for chest compressions in adult CPR. World Journal of Emergency Surgery 2011;6:41.

2. Hellevuo $\mathrm{H}$ et al. Deeper chest compression - More complications for cardiac arrest patients? Resuscitation 2013;84:760-5.

3. Darok M. Injuries resulting from resuscitation procedures. Forensic Pathology Reviews, Vol 1, Humana Press, Totowa, NJ, 2004, 293-303.

4. Hashimoto Y, Moriya F, Furumiya J. Forensic aspects of complications resulting from cardiopulmonary resuscitation. Legal Medicine 2007;9:94-9.

5. Smekal D, Johansson J, Huzevka T, Rubertsson S. No difference in autopsy detected injuries in cardiac arrest patients treated with manual chest compressions compared with mechanical compressions with the LUCAS device-A pilot study. Resuscitation. 2009;80:1104-7.

6. Buschmann CT, Tsokos M. Frequent and rare complications of resuscitation attempts. Intensive Care Med 2009;35:397-404.

7. Miller AC, Rosati SF, Suffredini AF, Schrump DS. A systematic review and pooled analysis of CPR-associated cardiovascular and thoracic injuries. Resuscitation 2014;85:724-31.

8. Meron $\mathrm{G}$ et al. Cardiopulmonary resuscitation-associated major liver injury. Resuscitation 2007;75:445-53.

9. Hoke RS, Chamberlain D. Skeletal chest injuries secondary to cardiopulmonary resuscitation. Resuscitation 2004;63:327-38.

10. Natsuaki $M$ et al. Right ventricular rupture induced by cardiopulmonary resuscitation. Journal of Cardiology Cases 2010;1:e42-4.

11. Gil Martin FJ, Perez Ordonez A, Castel Tarrio I, Morentin Campillo B. Liver laceration caused by cardio-pulmonary resuscitation manoeuvres. Emergencias 2009;21:148-50.

12. Natsuaki $M$ et al. Right ventricular rupture induced by cardiopulmonary resuscitation. Journal of Cardiology Cases 2010;1:e42-4. 
13. Adler SN, Klein RA, Pellecchia C, Lyon DT. Massive hepatic hemorrhage associated with cardiopulmonary resuscitation. Arch Intern Med 1983;143:813-4.

14. Clark DT. Complications following closed- chest cardiac massage. JAMA 1962,181:337-8

15. Krischer JP, Fine EG, Davis JH, Nagel EL. Complications of cardiac resuscitation. Chest 1987;92:287-91.

16. Ziegenfuss MD, Mullany DV. Traumatic Liver Injury Complicating Cardio-pulmonary resuscitation. The value of a major Intensive Care facility: A report of two cases. Critical care and Resuscitation 2004;6:102-4.

17. Sawyers Sommers M. The shattering consequences of CPR. How to asses and prevent complications. Nursing92, July.

18. Umach $\mathrm{P}$, Unterdorfer $\mathrm{H}$. Massive organ injuries resulting from resuscitation measures. BeitrGerichtl Med 1980;38:29-32
19. Kouzu H et al. Delayed visceral bleeding from liver injury after cardiopulmonary resuscitation. The Journal of Emergency Medicine 2012;43:e245-8.

20. Krammer B, Steiner M, Burstein C, et al. Spontaneous, massive liver hemorrhage as a complication of thrombolysis with ultra-high dose streptokinase in deep thrombophlebitis. Vasa 1994;23:373-6.

21. Pollak S, Reiter C, Stellwag-Carion C. 2-Stage rupture of the liver as a complication of external heart massage. Z Rechtsmed 1984;92:6775 .

22. Krischer JP, Fine EG, Davis JH, Nagel EL. Complications of cardiac resuscitation. Chest 1987;92:287-91.

23. Curcă GC et al. Cardiac lesions associated with cardio-pulmonary resuscitation. Rom J Leg Med 2011;19:1-6.

24. Buschmann C, Schulz T, Tsokos M, Kleber C. Emergency medicine techniques and the forensic autopsy. Forensic Sci Med Pathol 2013;9:48-67. 